\title{
DOES THE MALE PROGRAMMING STUDENT THINK FEMALES SHOULD BE STUDYING COMPUTER TECHNOLOGY?
}

\author{
Jeanne M Baugh, Robert Morris University, Pittsburgh, PA, baugh@rmu.edu
}

\begin{abstract}
Many feel that Computer programming should be an essential part of the curriculum for a degree in Computer Information Systems. Additionally females are not going into computer careers in strong numbers and thus are not exposed to coding courses. This paper surveyed students taking introductory computer programming concerning their views on learning to program as well the role females play in computer technology. Most of the males surveyed reported that females are a better fit in fields such as nursing and that nothing extra should be done to attract them to computer and technology. As a contradiction, they reported valuing their female instructors more than their male counterparts. There have been a number of programs instituted to show females they belong in computer and technology fields. These programs must also include the education of men as well. Boys must see that the girls can do it too.
\end{abstract}

Keywords Computer Programming Course, Females in Technology, Computer and Information Systems Curricula

\section{INTRODUCTION}

Information systems curricula have existed for about fifty years. During the past decade there has been a decrease in the number of students in Information Systems programs. In addition, in some programs as many as $70 \%$ of students wash-out in programming sequences. To make matters worse, the number of female students going into IS programs has declined even more than the males. All one has to do is to walk into a Computer Information Systems class on any campus and see the lack of female students.

Hundreds of thousands of jobs and career beginnings remain available to those who acquire an IS degree [1]. There is evidence that legislators are awakening to this reality: "Computer programmers are in great demand by American businesses, across the tech sector, banking, entertainment, you name it. These are some of the highest-paying jobs, but there are not enough graduates to fill these opportunities" (Marco Rubio, Senator, Florida, http://www.code.org).

Traditionally, the Information Systems program has had the requirement of computer programming. The bulk of IS business schools believe in the necessity for programming and database skills [3]. Approximately $99 \%$ of these schools offer at least one programming course and all offer database. Likewise, the 47 accredited ABET [2] programs offer multiple programming courses as well as database. In the Information Systems Model Curricula, [16] programming was omitted from the list of requirements for an IS degree. Many business schools and ABET accredited programs do not agree with this decision. Additionally, many of us IS educators find it difficult to understand the thought process of IS 2010 curriculum designers in not requiring programming.

Programming is a necessary skill. According the bureau of labor statics website (http://www.bls.gov), with a computing degree, a student could expect to earn about $\$ 70,000$ to start. Computer Science is the highest paying college degree and computer jobs are growing at two times the national average.(http://code.org) However, as can be seen in figure 1, students are not going into the field in big enough numbers to match the projected need. 


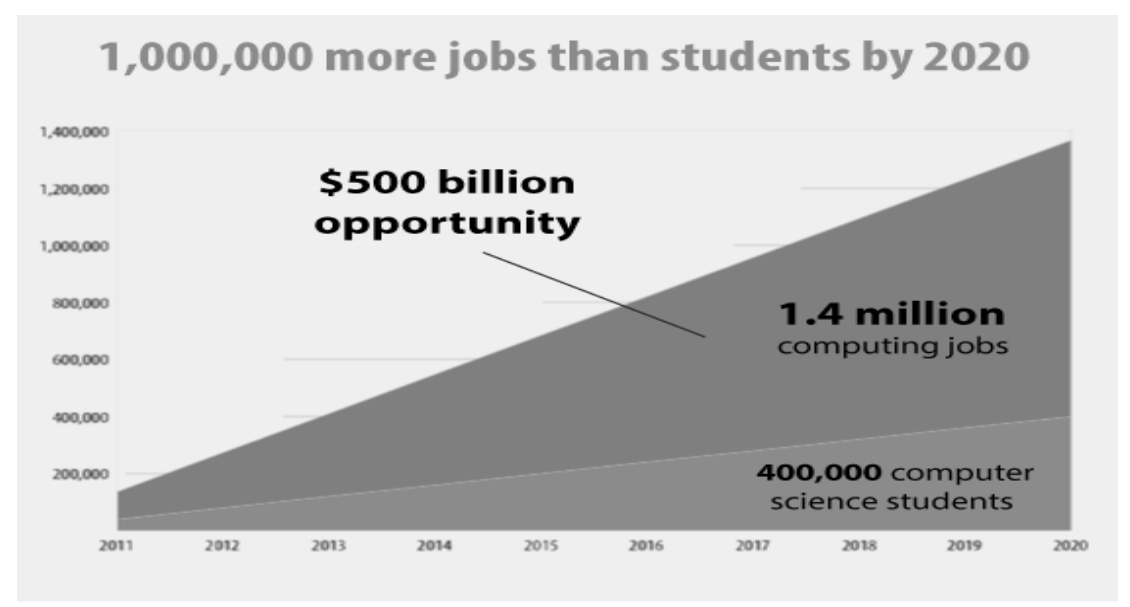

Figure 1. Job Projections According to Code.org

There are many advocates for requiring programming for all students: (http://www.code.org/quotes) Two examples of quotes on the site are: Susan Wojcicki, Senior Vice President, Google - "Learning to code makes kids feel empowered, creative, and confident" and Bill Gates, Chairman, Microsoft -"Learning to write programs stretches your mind, and helps you think better, creates a way of thinking about things that I think is helpful in all domains".

To make things worse, not only are there fewer students taking a coding course, fewer women are going into computer technology programs all together. "In the '50s and '60s, women made up about 30 percent of those working in technology, but then something societal happened where we put out this image that coding is only done by socially awkward males," [4] Women seemed to move away from coding and computer study. Female success in IT continues to decline [14]. We all need to adopt a new attitude: everyone can do it. The web site http://code.org supports a non-profit organization dedicated to promoting computer science (specifically computer coding) as a requirement for all students. Their vision states, "every student in every school has the opportunity to learn how to code."

It is alarming to see how few women are going into this area of study. There has been a great deal of research on why females are not going into computer fields and what can be done to encourage them to select computer majors $[13][15][10]$.

Is there some reason females do not feel comfortable in a computer curriculum? This female author has noticed the lack of females in her programming courses. Additionally this author has had a number of comments from male students concerning their surprise that they have a female for a programming instructor. In other related experiences, as an independent consultant for database programming, this author has actually had a number of males surprised that the data base work is being done by a female! These experiences have let the author to wonder how the male computer students perceive their fellow female students. Also how do both male and female students perceive the female faculty members of the Computer Information Systems Department? This study seeks to answer these questions and more.

\section{STUDENT SURVEY ATTITUDES TOWARD PROGRAMMING}

Perhaps one of the best indicators of the success of a course with the students is if they would recommend the course to their friends, even if it was not a required course. This question was asked in a previous study in 2014 [4] and the results on this current study are very close to what was found previously. Figure 2 represents this data. 


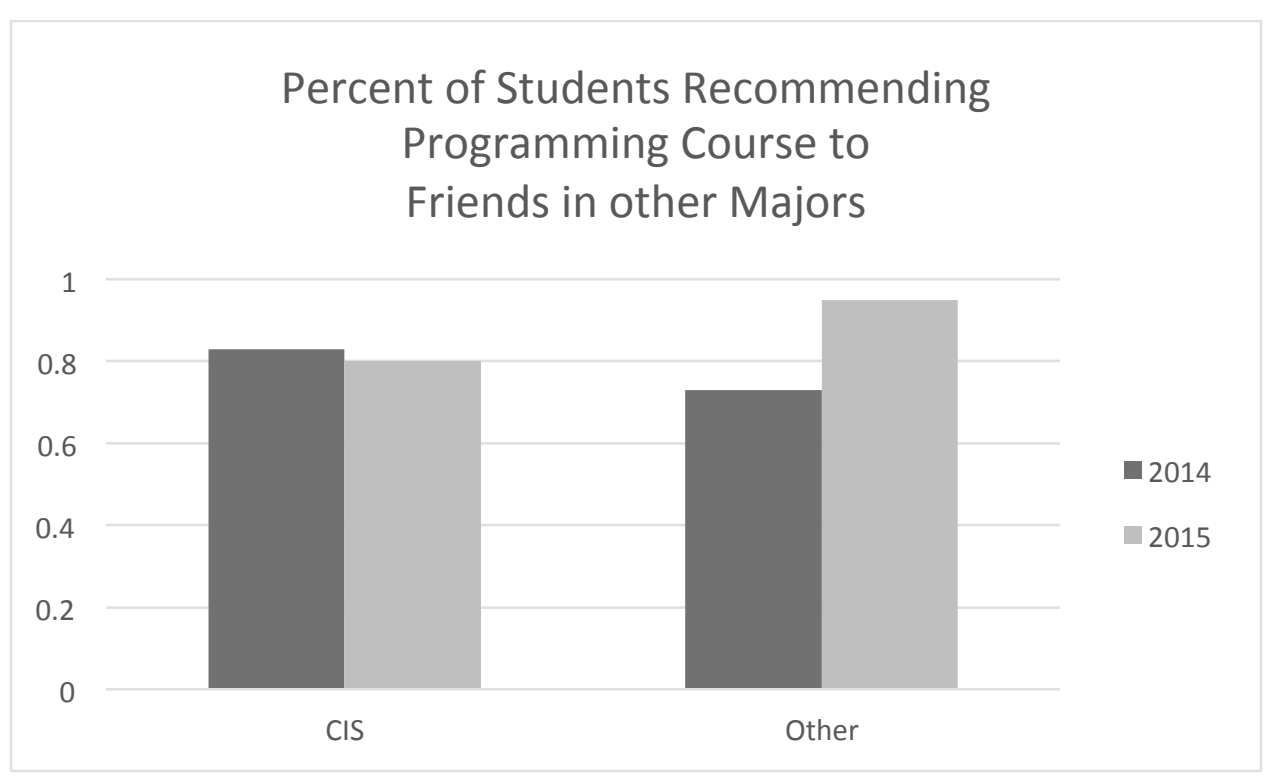

Figure 2. Recommendation to Take Programming Course

But not all are students are signing up for a programming course. Additionally, the number of females taking a programming course at the author's institution is almost non-existent and the number of females majoring in Computer and Information Systems very low. This reflects a nationwide trend.

Research exists as to why females are not going into Computer fields. Additionally there have been a number of programs instituted to try to attract females to these fields, which are having some success. In 2007, the National Center for Women \& Information Technology created a program called "Aspirations in Computing." It is a recognition and talent-development program for high school girls who demonstrate interest and aspirations in technology.

But, are male attitudes towards females in computer fields a hindrance to women going into the field, let alone succeeding in it?

\section{STUDENT SURVEY ATTITUDES CONCERNING GENDER}

According to a number of studies, the low number of women in math and science is mainly attributed to the negative effects and consequences of gender stereotyping, preferring males overfemales [14][15]. Some studies have even shown that women are seen as not competent [13].

An area that has been somewhat neglected is how do males perceive females in computer fields. How do they feel about fellow female students as well as their female instructors? Forty-eight students enrolled in beginning $\mathrm{C}++$ and Java were surveyed concerning their views on learning to program and the role females have in the Computer field.

\section{Demographics of the Students Surveyed:

$\begin{array}{lll}\text { Student's Gender: } & 40 \text { Male } & 8 \text { Female } \\ \text { Student's Major: } & 22 \text { CIS } & 26 \text { Engineering or other } \\ \text { Student's Year: } & 4 \text { Freshman } & 442^{\text {nd }} \text { year or higher }\end{array}$

\section{Number of Computer Classes each Student has Taken:}

$\begin{array}{ll}\text { Less than 3: } & 15 \text { students } \\ 3 \text { to } 5 \text { classes } & 18 \text { students } \\ \text { More than } 5 \text { classes: } & 14 \text { students }\end{array}$


Table 1 lists some of the responses to survey questions. It must be noted that since only 8 of the students surveyed were females, more research should be done with females in the future.

Table 1. Survey Responses

\begin{tabular}{|l|l|l|}
\hline \multicolumn{1}{|c|}{ Question } & \multicolumn{1}{|c|}{$\begin{array}{c}\text { Female Responses } \\
\text { (8 students responded) }\end{array}$} & \multicolumn{1}{c|}{$\begin{array}{c}\text { Male Responses } \\
\text { (40 students responded) }\end{array}$} \\
\hline $\begin{array}{l}\text { How interested are you in learning to } \\
\text { program? }\end{array}$ & $75 \%$ extremely interested \\
\hline $\begin{array}{l}\text { Would you recommend taking a } \\
\text { programming class to a friend? }\end{array}$ & $100 \%$ Yes & $84 \%$ Yes \\
\hline $\begin{array}{l}\text { How free do you feel to express your ideas } \\
\text { freely in class? }\end{array}$ & $62 \%$ Very free & $35 \%$ Very free \\
\hline $\begin{array}{l}\text { Are you surprised that there are not many } \\
\text { females in your programming class? }\end{array}$ & $\begin{array}{l}75 \% \text { said it does not surprise } \\
\text { them }\end{array}$ & $\begin{array}{l}75 \% \text { said it does not surprise } \\
\text { them }\end{array}$ \\
\hline $\begin{array}{l}\text { Do you prefer to work in groups with } \\
\text { students of your own gender? }\end{array}$ & $75 \%$ said does not matter & $100 \%$ said does not matter \\
\hline $\begin{array}{l}\text { Which gender of instructor are you most } \\
\text { comfortable with? }\end{array}$ & $75 \%$ said does not matter & $92 \%$ said does not matter \\
\hline $\begin{array}{l}\text { Which gender of instructor is the most } \\
\text { knowledgeable of computer programming? }\end{array}$ & $100 \%$ Both the same & $\begin{array}{l}6 \% \text { Male } \\
2 \% \text { Female } \\
90 \% \text { Both the same } \\
2 \% \text { Do not know }\end{array}$ \\
\hline
\end{tabular}

The results of these questions do indicate a few things. The males are not surprised that there are not many females in their classes, but report that they have no preference between male and female instructors. Ninety percent of the males report that both the female and male instructors possess the same knowledge of computers, but what will be see in this paper is that their comments do not support this result. The male view of female instructors seen in Table 1 may be the case for some males studied, but responses to a number of opened questions cast a doubt on this supposition.

Males indicated that females may not want to go into these technology fields, and that many only want fields they see as female related, such as education and nursing. A few male students even said that "nothing" should be done to attract females.

Interestingly the males reported that they liked their female computer instructors better than their male instructors. But do they really think their female colleagues in their classes are equal to them? To try to elicit rich data on this important issue, a number of open ended questions were also presented to the students in this survey. The responses to these questions bring the true underlying views to the surface.

In looking at the responses to the questions in Table 2, one would think that the males support females going in the computer field whole heartedly. But when asked why they are not going into the computer field, most of the responses were very sexist. The following statements are very representative of male responses:

- "Most females don't think they can do it; Don't want to do it"

- 'I feel as if technology in general is a 'Male' field, its not anyone's fault, or sexist, it just happens that way. Men and Woman enjoy different things, that is a fact"

- "It is just more 'normal' to see male students in these types of courses"

- "Females don't like computers as much as males"

- "females like nursing"

- "computing related fields are usually male dominated"

- "Because most of the female are in nursing or Psychology"

- "I believe that females think that computer programming classes are nerdy"

- "To me girls aren't really that much into computers. My mom has worked with a computer all her life but she only knows how to use one program that she needs for work and that is it. She needs me to help even turn the computer on" 
- "I just don't think that programming is something that would interest a female in general" "The IT world is dominantly male. Same as the world of nursing is dominantly female"

- "A lot of girls aren't interested in computer stuff"

Almost all of the responses indicate that the computer field is not for females.

Additionally, when asked what can be done to attract females, the male responses were again disturbing, some of which are:

- "Have some of the classes to be very simple to understand"

- "Relate the computer topics towards feminine things"

- "I think its doing fine now"

- "Perhaps try to group more females into the same class sections, so they feel more comfortable"

- "Add more computer courses for nursing or other popular majors that females take"

- "Create the courses with a fun twist involved"

- "Tell them they can work the computers as well as males can"

- "They'll eventually figuring out that it is a possible career"

- "Nothing. Females are just as welcome as males"

- "Nothing, nothing should have to be done. Computer courses do not try to 'attract' males, it is just that way. It would be like fashion designers trying to 'attract' male workers, its ridiculous and not needed"

There were a few male comments that were constructive in terms of what can be done to help attract females:

- "There would need to be a complete replacement of the programmer image"

- "I think that to attract more females, there would have to be more of a pull for how computer classes really can influence them in the real world"

- "Have females that grow up learning about computers"

- "I believe the solution is to start teaching computer material at a younger age"

- "advertise and try to gain attention by those people who took this major and succeeded females"

The comments reported indicate a general consensus of opinion from most males concerning female representation in the computer classes. The majority of the comments either felt that nothing should be done and that computers are a male field. But, they think female instructors are just fine and actually somewhat preferred to males.

Although there were only 8 females in this study, their responses to this question should be noted. Each one of them felt that girls should be educated at a young age about the opportunities that abound with a computer degree. Two key words that showed up in almost all of the female responses; "education" and "young". This does make sense. Much research has shown that this is the case. If girls are educated about technology when they are young, they will see this as a possibility for their future.

Even though many of these males feel that females don't need to be encouraged to go into the computer field, they have contradicting feelings concerning their female instructors. As stated earlier, $92 \%$ of the male students reported that it did not matter what gender their instructor was. When asked how they feel about female instructors, male students reported that they felt the female instructors are more patient, understanding and willing to help. They also said that the female instructors care more about their students than their male counterparts. Additionally they were surprised that there were more females instructors than they had expected. Clearly, they see that females are successful in computer technology. But they do not appreciate that young girls should be encouraged to become one of these "caring and supportive educators".

The demographics of the male students in this study had no major impact on the outcome. When the data was analyzed according to various criteria as listed in Table 2, it can be seen that the male students all felt females were not really interested in the computer filed and therefore there was no need to encourage them. 
Table 2. Male Demographic Attitudes

\begin{tabular}{|l|c|c|c|}
\hline \multicolumn{1}{|c|}{$\begin{array}{c}\text { Category of Male } \\
\text { Students }\end{array}$} & $\begin{array}{c}\text { Majority Feel the } \\
\text { Computer Field Should } \\
\text { be Attractive to Females }\end{array}$ & $\begin{array}{c}\text { Majority Feel Female } \\
\text { Sudents Need to be } \\
\text { Encouraged to go into } \\
\text { Computer Field }\end{array}$ & $\begin{array}{c}\text { Majority Feel Positive } \\
\text { about their Female } \\
\text { Computer Instructors }\end{array}$ \\
\hline CIS Majors & NO & NO & YES \\
\hline Engineering Majors & NO & NO & YES \\
\hline $\begin{array}{l}\text { Students in their first } \\
\text { year of study }\end{array}$ & NO & YES & YES \\
\hline $\begin{array}{l}\text { Students in 2nd to 4 } \\
\text { year of study }\end{array}$ & NO & NO & YES \\
\hline $\begin{array}{l}\text { Students who have taken } \\
\text { less than 3 computer } \\
\text { courses }\end{array}$ & NO & YES & YES \\
\hline $\begin{array}{l}\text { Students who have taken } \\
3 \text { or more computer } \\
\text { courses }\end{array}$ & NO & NO & \\
\hline
\end{tabular}

\section{CONCLUSIONS}

In a society where women are not only encouraged to pursue a career path of their choice, but are also protected against gender discrimination in that path, one would think that young people would have embraced these two concepts. However, in this small study, it is very clear that is not the case. There is still a gender divide as to what careers are seen by some young men as being appropriate for women. Interestedly enough, the small number of women in the study did see that they belong in a computer field. But the majority of men did not feel the same. These male programming students, for the most part felt that it makes sense that women would not enter a computer program of study, because, as is evidenced by this study, they feel women pursue other areas they see as being "more female". This is a throwback to the gender stereotyping of the 1970's. Further, these males felt that it is not necessary to even try to encourage women to seek these fields.

The gender biased views of these male students is even more difficult to understand in that they all reported very positive attitude toward their female instructors. One would think the positive role model these female instructors provide would influence them into seeing that women are suited for these computer careers just as much as men are. But sadly, this is not the case.

But where to begin? Much is already being done to empower females in the area of science and technology. Some of the programs have had success. But, it is clear that it is not enough to educate the females about the possibilities of a career in the computer field. The males also need to be educated. This education must start at an early age. Males along with females must be presented with situations in which they work together with no hint of gender bias. Because many young girls are sensitive to what others think about them, especially the boys, it is important that they are not seen them as different in terms of their technology abilities. Teachers need to be educated to show no gender bias.

Young boys and girls should be given the chance to interact with female computer professionals. This will benefit both genders. Maybe by the time they grow up, seeing females going into this profession will be absolutely normal.

At an early age, both boys and girls should be given computer projects to work on together. Studies have shown that awareness of gender stereotypes has already started during the preschool years [9]. Again, teachers must show no gender preference in the classroom. 
Parents of course should support their children in their educational path, but girls should be given every opportunity to expand their horizons in the area of technology. Happily, there are now more and more toys and games etc...on the market that provide technology activities while of course being fun.

Finally, yes the females need to be educated at a young age as to the opportunities in computer technology. But, the males have to be taught that it is perfectly okay for females to be programmers, systems administrators, database designers etc... The boys need to grow up having a different view of the girl's technical abilities, so the girls will not feel different! A whole generation of children growing up together as equals in technology hopefully will translate to more girls choosing technology as a career, successfully progressing in that career and ultimately happy in their choice of careers.

\section{REFERENCES}

1. Aasheim, C., Shropshire, J., Li, L., Kadlec, C. (2012). Knowledge and Skill Requirements for Entry-Level IT Workers: A Longitudinal Study, Journal of Information Systems Education. Summer2012, Vol. 23 Issue 2, p193-204

2. Accreditation Board for Engineering and Technology (ABET) http://www.abet.org

3. Apigian, C.H. and Gambill, S.E. (2010). Are We Teaching the IS2009 Model Curriculum? Journal of Information Systems Education, Vol. 21(4), p411-420.

4. Barua, A., \& Barua, A. (2012). Gendering the digital body: Women and computers. AI \& Society, 27(4), 465477. doi:http://dx.doi.org/10.1007/s00146-012-0371-9

5. Baugh, J.M., Kovacs,P. (2012). Large Programming Projects for the beginning programmer, Issues in Information Systems, Volume 13, Issue 1, pp. 85-93, 2012

6. Baugh, J.M, \& Kovacs, P.J., (2014). Programming Not Required? Did The IS-Model Curriculum Get It Right?, Issues in Information System, XV(1), 399-408.

7. Chen-yao Kao,Soc, "Mathematically gifted adolescent females' mixed sentiment toward gender stereotypes" Psychol Educ (2015) 18:17-35 DOI 10.1007/s11218-014-9278-2

8. Davis, G. A., \& Rimm, S. B. (2004). Education of the gifted and talented (5th ed.). Boston: Allyn \& Bacon.

9. Kurtz-Cortes, B., Rowley, S. J., Harris-Britt, A., \& Woods, T. A. (2008). Gender stereotypes about mathematics and science and self-perceptions of ability in late childhood and early adolescence. Merrill-Palmer Quarterly, 54(3), 386-409.

10. Miles, R. Y. (2009). The challenges and factors that determine female career choices in information technology professions: An exploratory investigation (Order No. 3378954). Available from GenderWatch; ProQuest Dissertations \& Theses Global. (305161772). Retrieved from http://search.proquest.com/docview/ 305161772 ? accountid $=28365$

11. Mishra, S., Caputo, D. J., Leone, G. J., Kohun, F. G., \& Draus, P. J. (2014). The role of awareness and communications in information security management: A health care information systems perspective. International Journal of Management \& Information Systems (Online), 18(2), 139-138. Retrieved from http://search.proquest.com/docview/1516951161 ?accountid=28365

12. Preckel, F., Goetz, T., Pekrun, R., \& Kleine, M. (2008). Gender differences in gifted and average-ability students: Comparing girls' and boys' achievement, self-concept, interest, and motivation in mathematics. Gifted Child Quarterly, 52(2), 146-159.

13. Raines, L. (2011, Jan 09). Technology in need of more women: Females account for 24 percent of tech jobs in 2008. book tries to draw girls into the field. The Atlanta Journal - Constitution Retrieved from http://search.proquest.com/docview/822839988?accountid=28365

14. postmedia, n. u. (2011, Jul 23). Number of women in technology fields declining; last year's data shows that only about 25 per cent of information technology employees were women. The Times - Transcript Retrieved from http://search.proquest.com/docview/878710386?accountid=28365

15. Ramnanan, G. P. (2001). A study on increasing the interest and involvement of females (ages 14 to 18) in technology through skills development and mentoring (Order No. 3026531). Available from ProQuest Dissertations \& Theses Global. (304772204). Retrieved from http://search.proquest.com/docview/304772204? accountid $=28365$

16. Topi, H., Valacich, J., Wright, R.T., Kaiser, K.M., Nunamaker, J.F., Sipior, J.C., and Vreede, G.J. (2010). IS 2010 Curriculum Guidelines for Undergraduate Degree Programs in Information Systems, Association for Computing Machinery (ACM), Association for Information Systems (AIS)", retrieved July 14, 2012: http://www.acm.org/education/curricula/IS\%202010\%20ACM\%20final.pdf 